\title{
Energy consumption of bridge construction: conventional vs precast girders
}

\author{
Jati Utomo Dwi Hatmoko*, Subrata Aditama K.A. Uda, Arya Desta Andika, Amelia \\ Kristina Putri \\ Civil Engineering Department, Diponegoro University, Semarang - Indonesia
}

\begin{abstract}
One of the ways to reduce the negative impact of construction projects on the environment is reducing energy consumption. This study aims to calculate the energy consumption of a bridge construction project on the conventional beam girder and the precast girder. Data collection was carried out on the Salatiga-Surakarta toll road bridge project package 4.1 through field observations and interviews with project stakeholders. The results showed that the estimate of conventional girder energy consumption during the raw material transporting stage is $2.857 \mathrm{MJ} / \mathrm{km} \cdot \mathrm{m}^{3}(4.87 \%)$, during the production is $19.989 \mathrm{MJ} / \mathrm{km} \cdot \mathrm{m}^{3}(34.11 \%)$, during the transporting to the location is $3.56 \mathrm{MJ} / \mathrm{km} \cdot \mathrm{m}^{3}(6.07 \%)$, and lastly, during the construction stage is $32.201 \mathrm{MJ} / \mathrm{km} \cdot \mathrm{m}^{3}(54.94 \%)$. While the estimate of energy consumption of precast girder at the raw material transporting stage is $2,897 \mathrm{MJ} / \mathrm{km} \cdot \mathrm{m}^{3}(5.27 \%)$, during the production is $49.627 \mathrm{MJ} / \mathrm{km} \cdot \mathrm{m}^{3}$ $(90.29 \%)$, the transporting to the location is $0.957 \mathrm{MJ} / \mathrm{km} . \mathrm{m}^{3}(1.74 \%)$, and during the construction stage is $1.485 \mathrm{MJ} / \mathrm{km} \cdot \mathrm{m}^{3}(2.70 \%)$. The total energy consumption of conventional girders is $58.606 \mathrm{MJ} / \mathrm{km} . \mathrm{m}^{3}$ $(51.60 \%)$, while for precast girder is $54.965 \mathrm{MJ} / \mathrm{km} \cdot \mathrm{m}^{3}$ (48.40\%). The conventional girder energy consumption is $3.20 \%$ greater than the precast girder, thus, in this case, the precast girder is the best alternative to reduce the energy consumption during bridge construction activities. This study provides an understanding of environmental impacts based on the amount of energy consumption of conventional and precast girders, which is useful in the selection of girder beam types that are more environmentally friendly.
\end{abstract}

\section{Introduction}

The construction sector is responsible for the use of $40 \%$ of global energy, $25 \%$ of global water and $40 \%$ of global resources emitted into the atmosphere as much as one-third of the world greenhouse gas (GHG) emissions. In addition, during the operational stage of buildings around $60 \%$ of world electricity is also consumed [1]. Construction activities are also the main source responsible for environmental impacts resulting from material processing, transportation, use of equipment duringthe construction process, demolition process [2].

Infrastructure projects, particularly road projects, are related to a large amount of $\mathrm{CO} 2$

\footnotetext{
* Corresponding author: jati.hatmoko@,ft.undip.ac.id
} 
emissions from the initial stage of the project to the demolition [3]. The construction process will have an impact, such as changing the condition and function of nature and consumption of nonrenewable natural resources. Therefore, it is necessary to apply the principles of sustainable development with an environmental perspective or green construction. Green construction is the practice of building and implementing processes that pay attention to the environment and resource efficiency throughout the life cycle of a building from the planning, construction, operation, maintenance, renovation, and deconstruction stages. The concept of Green Construction promotes environmentally friendly construction through work methods, use of materials, use of construction equipment, management, and supervision [4]. Green construction is the planning and implementation of construction that prioritizes human health and the environment in minimizing pollution and waste levels and reducing environmental damage throughenergy, water and other resource efficiencies [5].

Green building is a development concept that leads to the structure and use of processes that pay attention to the environment and save resources throughout the life cycle of the building, from site selection to construction design, operation, maintenance, renovation, and demolition. Green Building Concept, which is a physical building concept that promotes environmentally-friendly efforts during the operation stage through several criteria, such as the use of building materials, energy use, air and light circulation conditions, water conservation in building, land use, and environmental management around building [4]. Green building aims to maintain the environmental balance of activities duringthe building life cycle to reduce environmental impacts from both planning structures and environmentally friendly resources by minimizing energy, water, pollution and waste and improving the quality of human life $[6,7,8]$.

Importantaspects of designing sustainable roads are movement, ecology, and community. This is stated in several design examples up to the implementation of road construction. The movement in question is the movement of road users and goods of all destinations using all modes [9]. Green roads are a standard proposed to measure sustainable development practices related to road design and construction. Sustainable development here is defined as the characteristics of the system that reflects the ability of the system to support natural laws and human values [8]. Green roads apply to the design and construction of new or rehabilitated highways including expansion or redesign. Specifically, this applies to the design process, construction activities, as well as material transportation activities, Portland Cement Concrete (PCC) production, and Hot Mix Asphalt (HMA).

Figure 1 shows the relationship between green construction, green building, and green roads [10]. The concept of green construction is more emphasized on the process or activities at the construction implementation stage starting from the initiation, design, to construction activities, while the concept of green building, is more functional than the physical structure of a building during the operational period and the implementation of building demolition. Green road is the implementation of the green concept in road and bridge development activities that prioritize an environmentally friendly and sustainable building. This study aims to calculate the energy consumption of a bridge construction project on the conventional beam girder and the precast girder. 


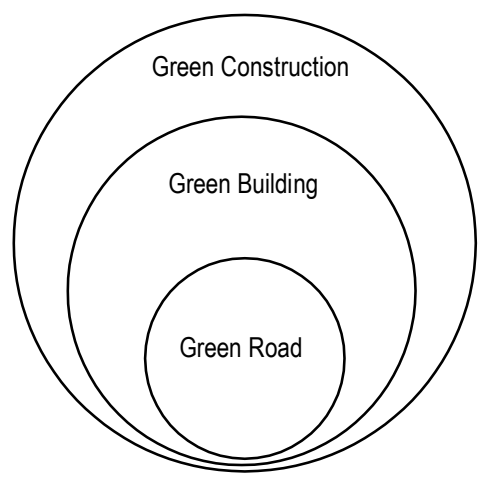

Fig. 1. The relationship between Green Construction, Green Building, and Green Road [10].

\section{Concrete Bridge}

Construction of a bridge cannot be separated from the flow of material sources obtained and processing materials into a product untilthe productisused by consumers. Concrete bridges have two types, i.e. conventional bridges and pre-stressed bridges.

Construction of a typical reinforced concrete bridge (figure 2) with the type of upper structure in the form of a slab is efficient only in short spans. Slab bridges from pedestal are not supported by girder or transverse beam (stringer). Concrete slab bridges are reinforced using reinforcing steel in the longitudinal and transverse directions so that they can distribute lateral suction loads [11].

Prestressed bridges are bridges in which the steel reinforcement is prestressed against the concreteto increase the concretestrengthto withstand externalloads. Forprestressedbridges, there is a girder used for connecting inter piers or abutments [12]. Thereare two types of the process of prestressing the steels, i.e. prestressing prior to casting concrete (pre-tensioning), and prestressing after casting concrete(post-tensioning) [13,14].

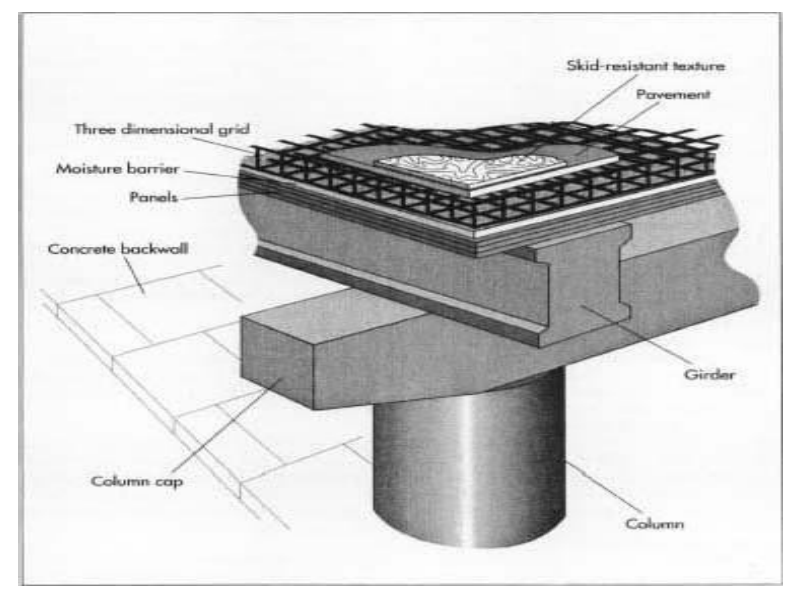

Fig. 2. Typical details of reinforced concrete bridge construction

\section{Girder}

Girder is a beam connecting two supports in the form of piers or abutments on a bridge or an 
overpass. The shape of the girder is generally profiled I, T profile, box (box girder), or other forms. According to the constituent materials, there are concrete girders and steel girders. Meanwhile, according to the design system, there are conventional girder (cast in place) and precast girder[11]. The choice of girder shape usually adjusts to the locationand the design of the track. For example, profile I girder is effective if it is used on a straight road, but if a bridge is built with horizontal curves/alignment, it is less effective because it is weak against torque strength[12].

Conventional girder is also known as cast in place girder, which is cast directly at the construction site of the bridge. The girders are designed following the design of concrete in general, which uses formwork as a mould. Precast girder is a concrete girder which production process is carried out in a factory and then taken to the construction site of a bridge or overpass. Table 1 shows the stages of the energy consumption cycle in girder beam manufacturing and installation activities [15].

I-shaped girder is often called PCI Girder, which can be made from composite materials or non-composite materials. In choosing materials, it is necessary to consider the type of strength required and the cost. Box girder is suitable for long-span bridges. Box girders are designed as continuous structures on pillars because girder boxes with prestressed concrete in the design are usually advantageous for continuous span. Box girders are generally shaped like a trapezoid or box. Girder with trapezoidal form gives more efficiency in the construction process than a box shape[12].

Table 1. Energy consumption cycle based on the stages of the cradle to grave girders [15]

\begin{tabular}{|c|c|c|}
\hline Stage & Conventional Girder & Precast Girder \\
\hline $\begin{array}{l}\text { Transporting } \\
\text { raw material }\end{array}$ & $\begin{array}{l}\text { The raw materials needed in the } \\
\text { manufacture of conventional girders } \\
\text { are aggregates (coarse, medium and } \\
\text { fine granules), sand, and cement. Each } \\
\text { raw material is sourced from a } \\
\text { different place, then collected at a } \\
\text { processing site called a batching plant. } \\
\text { The associated environmental impacts } \\
\text { at this stage are energy consumption } \\
\text { and emissions related to the use of } \\
\text { vehicles used as transportation, such as } \\
\text { dump trucks, wheel loaders, } \\
\text { excavators and bulk } \\
\text { carrier trucks. }\end{array}$ & $\begin{array}{l}\text { The raw materials needed in making } \\
\text { precast girder are aggregate (coarse, } \\
\text { medium, and fine granules), sand, } \\
\text { cement, and reinforcing steel. Each raw } \\
\text { material is sourced from a different place, } \\
\text { then collected at one manufacturing site. } \\
\text { The environmental impact that occurs is } \\
\text { the energy needs and emissions produced } \\
\text { by vehicles used for transportation such } \\
\text { as dump trucks, wheel loaders, } \\
\text { excavators and bulk carriertrucks. }\end{array}$ \\
\hline Production & $\begin{array}{l}\text { The production process uses a batching } \\
\text { plant. In general, batching plants are } \\
\text { divided into two types, i.e. dry mixed } \\
\text { and wet mixed. For the dry mixed, the } \\
\text { batching plant is only used for } \\
\text { weighing, the stirring is done in the } \\
\text { mixer truck barrel. While for the wet } \\
\text { mixed, from weighing to stirring, is } \\
\text { carried out at the batching plant. All } \\
\text { materials to be stirred need to be } \\
\text { weighed according to mixed- design } \\
\text { composition by taking into account the } \\
\text { water content in the aggregate or sand } \\
\text { material. }\end{array}$ & $\begin{array}{l}\text { At the manufacturing stage, the girders are } \\
\text { designed starting from assembling the } \\
\text { reinforcement to selecting the module } \\
\text { according to the Detail Engineering } \\
\text { Design (DED). In the plant, there is also a } \\
\text { batching plant to meet the needs of ready- } \\
\text { mixed concrete in the casting process. The } \\
\text { location of the batching plant is adjacent } \\
\text { to the manufacturing location, so that the } \\
\text { transportation process is done by using } \\
\text { truck mixers. The process of pouring } \\
\text { ready mixed concrete into the mould uses } \\
\text { a concrete } \\
\text { bucket. }\end{array}$ \\
\hline
\end{tabular}




\begin{tabular}{|c|c|c|}
\hline $\begin{array}{l}\text { Transporting } \\
\text { to the Site }\end{array}$ & $\begin{array}{l}\text { The transportation process uses a } \\
\text { truck mixer from the batching plant to } \\
\text { the planned girder casting location. } \\
\text { Usually, one mixer truck can hold } 6 \mathrm{~m} \\
3 \text { of concrete. The environmental } \\
\text { impacts associated at this stage are } \\
\text { energy consumption and emissions } \\
\text { related to the } \\
\text { use of vehicles used for transportation. }\end{array}$ & $\begin{array}{l}\text { Girder that is ready to be transported to } \\
\text { the trailer truck is assisted during the } \\
\text { lifting process using a mobile crane or } \\
\text { gantry crane. Environmental impacts that } \\
\text { occur at this stage are energy } \\
\text { consumption and emissions produced by } \\
\text { vehicles used fortransportation. }\end{array}$ \\
\hline Construction & $\begin{array}{l}\text { Before casting at this the construction } \\
\text { stage, reinforcement is placed the } \\
\text { design. During the process, } \\
\text { scaffoldings are used when it has } \\
\text { reached a certain height. A formwork } \\
\text { is installed after reinforcement is } \\
\text { complete. Fresh concrete that the } \\
\text { mixer truck carries when it arrives at } \\
\text { the planned location, is carried out by } \\
\text { a casting process is assisted by a } \\
\text { concrete pump or concrete bucket. } \\
\text { The environmental impacts } \\
\text { associated at this stage are energy } \\
\text { consumption and emissions related to } \\
\text { the use of construction machinery } \\
{[16]}\end{array}$ & $\begin{array}{l}\text { When the girder has arrived at the } \\
\text { construction site, the connecting process } \\
\text { is carried out following the sequence } \\
\text { number into one span of the girder and the } \\
\text { stressing process is then carried out. After } \\
\text { the girders are assembled into one, the } \\
\text { construction process is carried out onto } \\
\text { the pier head with the help of a gantry } \\
\text { crane or mobile crane, a mortar and } \\
\text { bearing pad are provided above the pier } \\
\text { head beforehand. The associated } \\
\text { environmental impacts at this stage are } \\
\text { energy consumption and emissions } \\
\text { related to the use of construction } \\
\text { machinery [16]. }\end{array}$ \\
\hline
\end{tabular}

\section{Research Method}

The object of this research is a bridge construction project of Salatiga-Surakarta Tol Road Project Package 4.1 which has two types of girders(figure 3) and different work methods for each type of girder, i.e. box girder with conventional work methods (cast in place) and PCI girder (Prestressed Concrete I) with the precast work method. The box girder has a span length of 36 meters and a width of 14 meters, while the precast girder has a span length of 56 meters with a width of 9 meters. This project is part of a toll road project designed to connect West Java to East Java, from which the sources of raw materials, formwork, steel used for the conventional girders, and equipment used during the construction process were identified. As for the precast girders, the data of raw materials and equipment were obtained from site observations and production data from the Waskita Concrete Precast Plant in Klaten.

This study measures the consumption of energy produced during the stages of material production, transportation, and construction using equation 1 . The calculation of the fuel requirements of each device varies according to the function and specification of the tool. The stage of material production includes the amount of energy associated with mining, processing, and production of construction materials. The material transportation stage includes the amount of energy-related to the transportation of construction materials from the source or factory to the project site. The construction stage includes the amount of energyrelated to the fabrication and installation of the girders. Technicaldata is obtained based on the amount of energy consumption in the stages of energy consumption activities which include the transporting of raw materials, the production stage, the stage of transporting to the site and the construction stage with the formulation of energy calculations in terms of fuel consumption [17].

$$
\text { Energy Consumption }\left(\frac{M j}{k m}\right)=\text { Fuel Consumption }\left(\frac{\text { litre }}{k m}\right) \times \text { Caloric Value } \frac{M j}{\text { litre }}
$$


Consumption at the stage of transporting raw material includes energy consumption in aggregate, sand, cement, and steel materials at the precast plant. The production stage includes energy consumption in material loading, electricity source, concrete pouring, concrete vibrator, erection, cutting and bending of steel. The transporting to the site stage includes energy consumption in the ready mix/precast concrete transporting, steel transporting, and formwork transporting. The construction stage includes energy consumption in concrete pouring and vibration, steel cutting, steel bending, formwork erection, reinforcement erection, and dismantling of formwork in conventional girders.

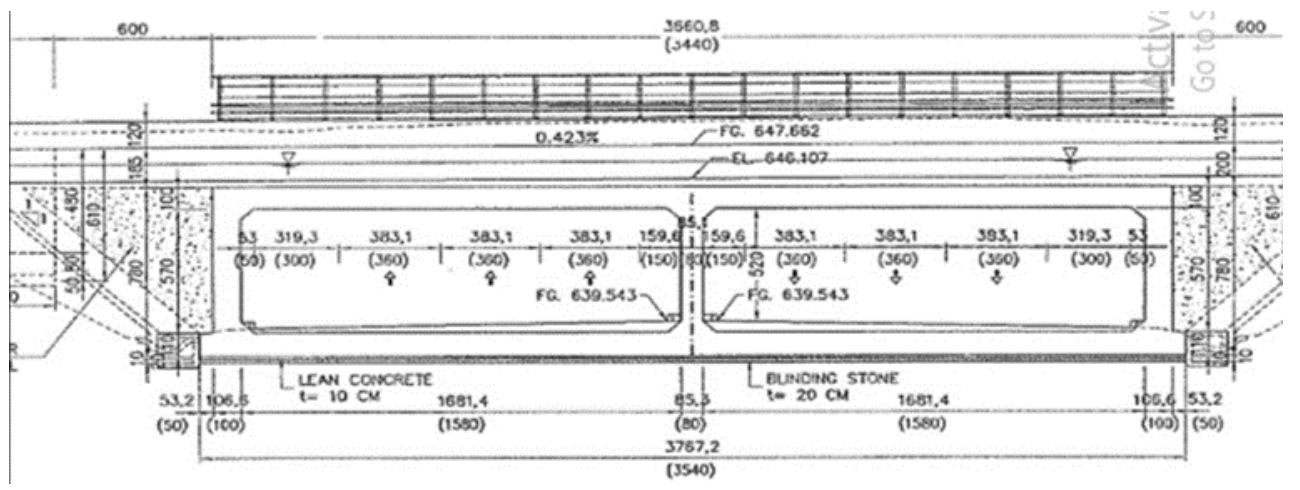

(a)

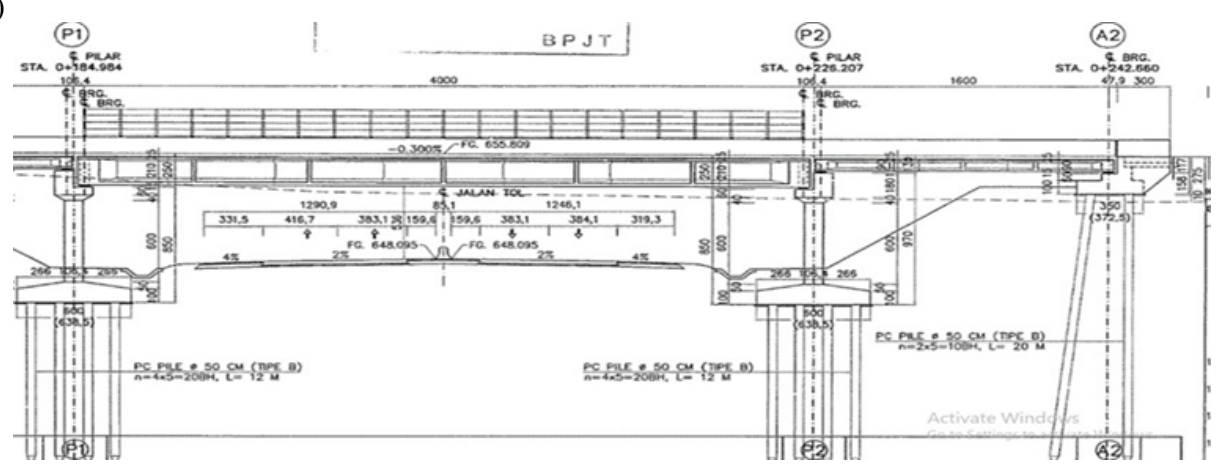

(b)

Fig. 3. Girder Types: (a) box girder/conventional; (b) Precast Girder

(Source: The Data of Toll Road Department Project Salatiga - Surakarta Package 4.1)

\section{Results and Analysis}

Table 2 shows the total energy consumption of conventional girders and precast girders according to the stages of work, i.e. transporting raw materials, production, transporting to site, and construction. The following sections explain the results in more detailed.

Table 2. Conventional and precast girder energy consumption

\begin{tabular}{|c|c|c|c|c|c|}
\hline \multicolumn{2}{|c|}{ Stage of Work } & \multicolumn{2}{c|}{ Conventional Grider } & \multicolumn{2}{c|}{ Precast Grider } \\
\cline { 3 - 6 } \multicolumn{2}{|c|}{} & $\begin{array}{c}\text { Energy } \\
\text { Consumption }\end{array}$ & $\begin{array}{c}\text { Total } \\
\text { Energy }\end{array}$ & $\begin{array}{c}\text { Energy } \\
\text { Consumption }\end{array}$ & $\begin{array}{c}\text { Total } \\
\text { Energy }\end{array}$ \\
\hline \multirow{3}{*}{$\begin{array}{c}\text { Transporting } \\
\text { raw material }\end{array}$} & Aggregate & 1.425 & & 1.508 & \\
& Sand & 1.198 & & 0.987 & \multirow{2}{*}{2.897} \\
& Cement & 0.234 & 2.857 & 0.356 & \\
\hline
\end{tabular}




\begin{tabular}{|c|c|c|c|c|c|}
\hline Production & $\begin{array}{c}\text { Loading } \\
\text { material } \\
\text { Power Source } \\
\text { Steel Cutting } \\
\text { Steel Bending } \\
\text { Concrete } \\
\text { Pouring } \\
\text { Concrete } \\
\text { Vibrating } \\
\text { Erection }\end{array}$ & $\begin{array}{c}3.12 \\
16.869 \\
- \\
- \\
- \\
- \\
-\end{array}$ & 19.989 & $\begin{array}{l}2.92 \\
16.865 \\
6.06 \\
9.022 \\
5.15 \\
4.28 \\
5.33\end{array}$ & 49.627 \\
\hline $\begin{array}{l}\text { Transportin } \\
\text { g to the } \\
\text { Site }\end{array}$ & $\begin{array}{c}\text { Ready mix } \\
\text { Concrete } \\
\text { Precast } \\
\text { Concrete } \\
\text { Formwork } \\
\text { Steel }\end{array}$ & $\begin{array}{c}3.42 \\
- \\
0.093 \\
0.0468\end{array}$ & 3.560 & $\begin{array}{c}- \\
0.957 \\
- \\
-\end{array}$ & 0.957 \\
\hline Construction & $\begin{array}{c}\text { Steel Cutting } \\
\text { Steel Bending } \\
\text { Formwork } \\
\text { Erection } \\
\text { Reinforceme } \\
\text { nt } \\
\text { Erection } \\
\text { Precast } \\
\text { Erection } \\
\text { Concrete } \\
\text { Pouring } \\
\text { Concrete } \\
\text { Vibrating } \\
\text { Formwork } \\
\text { Erection } \\
\text { deconstruction }\end{array}$ & $\begin{array}{c}6.239 \\
9.27 \\
0.0795 \\
0.259 \\
- \\
11.98 \\
4.28 \\
0.093\end{array}$ & 32.201 & $\begin{array}{c}- \\
1.485 \\
- \\
-\end{array}$ & 1.485 \\
\hline \multicolumn{2}{|c|}{ TOTAL ENERGY } & & 58.606 & & 54.965 \\
\hline
\end{tabular}

\subsection{Energy consumption in the raw material transporting stage}

The energy consumption at the stage of transporting raw materials to the plant or batching plant is shown in Figure 4. It can be seen that the total energy consumption of aggregate materials is higher than the energy consumption of sand and cement. At the stage of transporting raw material to the factory or batching plant, the energy consumption of aggregate material and cement of the precast girder is greater than the total energy consumption of aggregate material and cement of the conventional girder, which are $1.508 \mathrm{MJ} / \mathrm{km} \cdot \mathrm{m}^{3}$ and $0.356 \mathrm{MJ} / \mathrm{km} . \mathrm{m}^{3}$. While the energy consumption of aggregate materials and cement produced by conventional girders are $1.425 \mathrm{MJ} / \mathrm{km} . \mathrm{m}^{3}$ and $0.234 \mathrm{MJ} / \mathrm{km} . \mathrm{m}^{3}$. For energy consumption of sand material, the conventional girder shows greater results than the precast girder, which is $1.198 \mathrm{MJ} / \mathrm{km} . \mathrm{m}^{3}$, while the energy consumption of sand material of the precast girder is $0.987 \mathrm{MJ} / \mathrm{km} . \mathrm{m}^{3}$. In transporting steel material for precast girder, it consumes energy of $0.0455 \mathrm{MJ} / \mathrm{km} . \mathrm{m}^{3}$. 


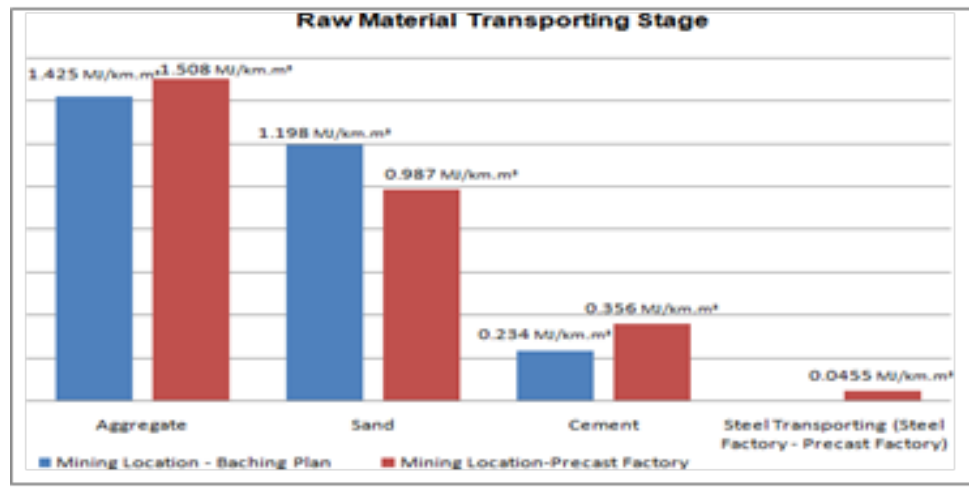

Fig. 4. The energy consumption at the raw material transporting stage

\subsection{Energy consumption at the production stage}

The result of energy consumption in the conventional girder production stage and precast girder is shown in Figure 5. The graph shows that the precast girder production activities are more than the conventional girder, therefore at this stage the energy consumption of the precast girder is greater than the conventional girder. The energy consumption of the conventionalgirders in the process of loading aggregate material and sand into storage bin is $3.12 \mathrm{MJ} / \mathrm{m}^{3}$, while the consumption of precast girder energy for the same job is $2.92 \mathrm{MJ} / \mathrm{m}^{3}$. In the process of making ready-mix concrete, the energy consumption between conventional girder and precast girder is almost the same, that are equal to $16.869 \mathrm{MJ} / \mathrm{m}^{3}$ and $16.865 \mathrm{MJ} / \mathrm{m}^{3}$, because the production equipment used at the precast plant and batching plant has the same production capacity. The value of the energy consumption of precast girder in the stages of steel cutting, steel bending, concrete pouring, concrete vibration, and precast girder erection, has values of $6.060 \mathrm{MJ} / \mathrm{m}^{3}$, $9.0216 \mathrm{MJ} / \mathrm{m}^{3}, 5.150 \mathrm{MJ} / \mathrm{m}^{3}, 4.280 \mathrm{MJ} / \mathrm{m}^{3}$, and $5.330 \mathrm{MJ} / \mathrm{m}^{3}$. For conventional girders there are no such workbecause these are done on-site, while the manufacturing process of precast girder is carried out in the factory.

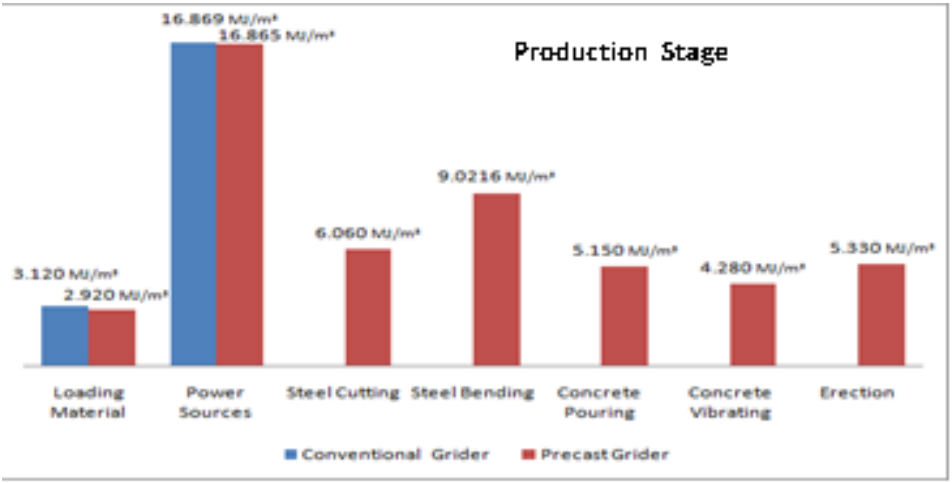

Fig. 5. The energy consumption at the production stage

\subsection{Energy consumption in transporting to the site stage}

The energy consumption in the transport stage of precast girder and conventional girder to the site is shown in Figure 6. The graph above shows the energy consumption produced by the conventional girder at the stage of transporting to the site is greater than the precast girder. In 
conventional girders, a mixer truck used as a carrier of ready-mix concrete consumes $3.42 \mathrm{MJ} /$ $\mathrm{km} . \mathrm{m}^{3}$ of energy. Whereas transporting precast girders consumes $0.957 \mathrm{MJ} / \mathrm{km} . \mathrm{m}^{3}$ of energy. The activities of formwork and steel transport at this stage are only found in conventional girders, which is equal to $0.093 \mathrm{MJ} / \mathrm{km} \cdot \mathrm{m}^{3}$ and $0.0468 \mathrm{MJ} / \mathrm{km} \cdot \mathrm{m}^{3}$.

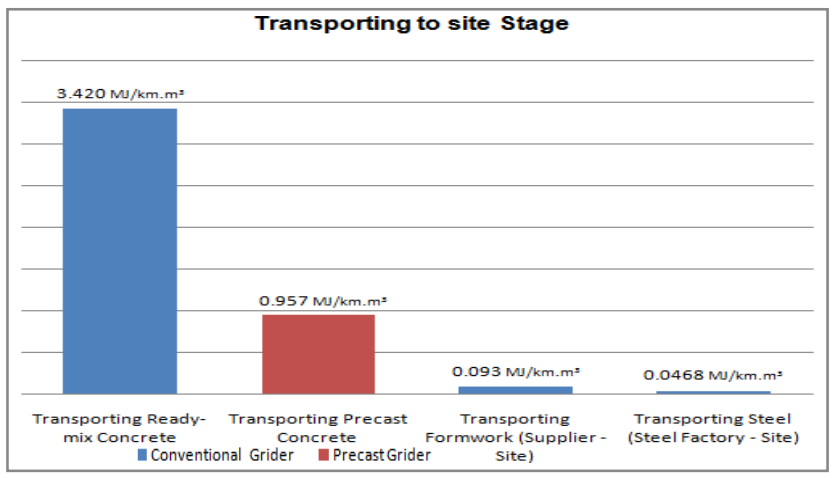

Fig. 6. The energy consumption at the stage of transporting to site

\subsection{Energy consumption in the construction stage}

The energy consumption in the construction stage of the precast girder and conventional girder is shown in Figure 7. The graph shows the energy consumption of the conventional girder during the construction stage is greater than the precast girder. In pouring concrete for conventional concrete girder (including the use of concrete vibrator) the energy consumption is $16.26 \mathrm{MJ} / \mathrm{m}^{3}$, which is greater than the precast concrete girder of $1.485 \mathrm{MJ} / \mathrm{km} . \mathrm{m}^{3}$. The energy consumption for steel cutting, steel bending, formwork erection, reinforcement erection, and dismantling of formwork in the conventional girders are $6.239 \mathrm{MJ} / \mathrm{m}^{3} ; 9.270 \mathrm{MJ} / \mathrm{m}^{3} ; 0.0795$ $\mathrm{MJ} / \mathrm{m} ; 0.259 \mathrm{MJ} / \mathrm{m}^{3}$ and $0.093 \mathrm{MJ} / \mathrm{m}^{3}$, respectively.

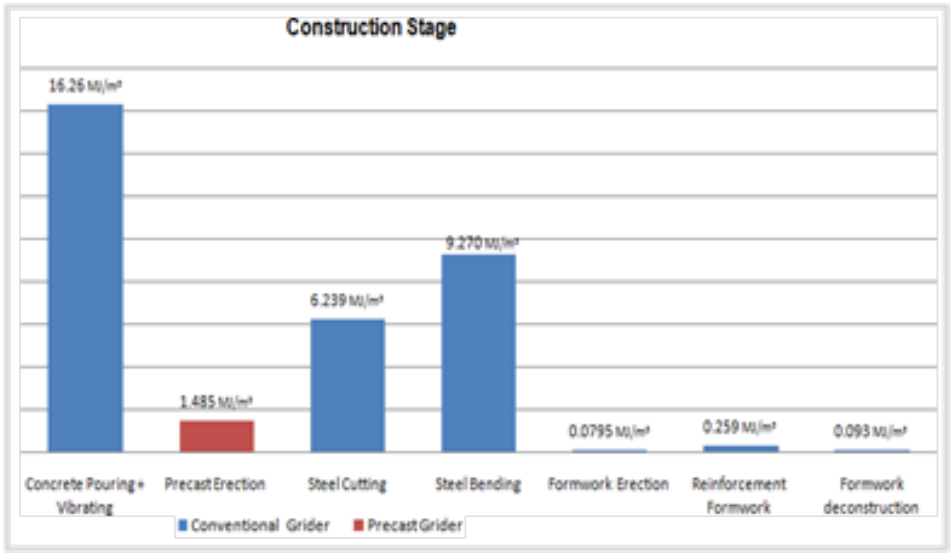

Fig.7. The energy consumption in the construction stage

\section{Discussion}

Table 3 shows the summary of the energy consumption of the conventional girders and precast girders according to the stages of the work. At the raw material transporting stage, the energy consumption of the precast girder is slightly greater than the conventional girder with a 
difference of $0.04 \mathrm{MJ} / \mathrm{km} \cdot \mathrm{m}^{3}$ or $0.68 \%$, which is less than $1 \%$. This indicates that the raw material transporting does not make a significant difference for both types of girders. At the production stage, the energy consumption of the precast girders is greater than the conventional girder with a difference of $29.638 \mathrm{MJ} / \mathrm{m}^{3}(42.57 \%)$. At this stage, the precast method has a significant impacton energy consumption.

In the transporting-to-site stage, the energy consumption of the conventional girder is greater than the precast one with a difference of $2.603 \mathrm{MJ} / \mathrm{km} \cdot \mathrm{m}^{3}(57.63 \%)$. This indicates that at this stage the cast-in-place method of the conventional girders is significantly consuming much more energy than the precast method. During the construction stage, the energy consumption of the conventional girders is far greater than the precast girder with a difference of $30.716 \mathrm{MJ} / \mathrm{m}^{3}(91.18 \%)$, thus the cast-in-place method of the conventional girders has a more significant effect in energy consumption. The total energy consumption of the conventional girders is $58.513 \mathrm{MJ} / \mathrm{km} . \mathrm{m}^{3}$, while for the precast girders is $54.965 \mathrm{MJ} / \mathrm{km} . \mathrm{m}$. This means that the total energy consumption of the precast girders is lower than the conventional girders with a difference of $3.548 \mathrm{MJ} / \mathrm{km} \cdot \mathrm{m}^{3}(3.20 \%)$.

Table 3. Summary of energy consumption

\begin{tabular}{|l|c|c|c|c|}
\hline \multirow{2}{*}{ Work Stages } & \multicolumn{2}{|c|}{ Conventional Grider } & \multicolumn{2}{c|}{ Precast Grider } \\
\cline { 2 - 5 } & Energy & Percentage & Energy & Percentage \\
\hline Transporting raw material & 2.857 & $4.87 \%$ & 2.897 & $5.27 \%$ \\
\hline Production & 19.989 & $34.11 \%$ & 49.627 & $90.29 \%$ \\
\hline Transporting to the site & 3.560 & $6.07 \%$ & 0.957 & $1.74 \%$ \\
\hline Construction & 32.201 & $54.94 \%$ & 1.485 & $2.70 \%$ \\
\hline TOTAL $\left(\mathrm{MJ} / \mathrm{km} \cdot \mathrm{m}^{3}\right)$ & 58.606 & $51.60 \%$ & 54.965 & $48.40 \%$ \\
\hline
\end{tabular}

Figure 8 shows the conventional girder having the largest percentage (54.94\%) in energy consumption at the construction stage. Meanwhile the energy consumption for the raw material transporting stage, transportation to the site, and production, each has a percentage of $4.87 \%, 6.07 \%$, and $34.11 \%$. For the precast girder, the production stage has the largest percentage $(90.29 \%)$ in energy consumption, while for the raw material transporting stage, transportation to the site, and construction, the percentages of energy consumption are $5.27 \%$, $1.74 \%$, and $2.70 \%$, respectively.

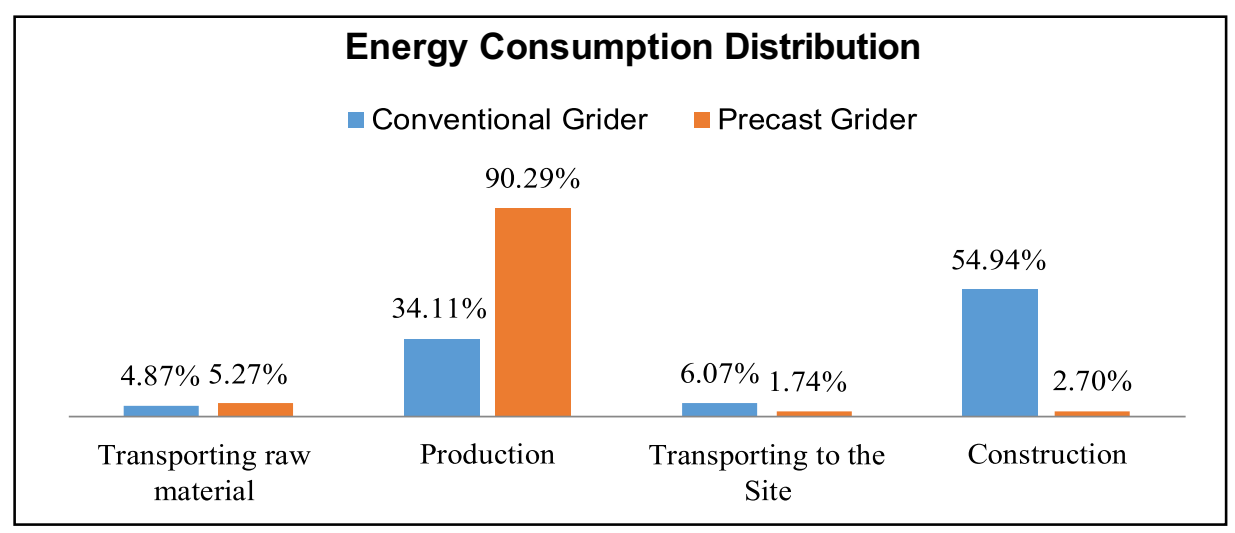

Fig. 8. Distribution of energy consumption of the conventional and precast girders

As for the precast girder, the fact that the production stage has the largest percentage of the energy consumption is consistent with research where the production stage is estimated to 
contribute $98 \%$ of energy consumption and emissions of GHGs to the project, while the construction stage is estimated to contribute $2 \%$ [17]. In this case, the energy used in material production is far greater than transportation and construction with a value of $693.151 \mathrm{MJ}$, whereas transportation is only $40.083 \mathrm{MJ}$ and construction is $73.734 \mathrm{MJ}$. The magnitude of the values of this energy consumption also means large GHGemissions, hence it is very important to minimize energy consumption on construction projects [19].

However, for the conventional girder, the biggest energy consumption is in the construction stage. This finding is in line with research which states that the amount of carbon emitted in the flexible pavement during production (off-site) is only $48.313 \%$, compared to the construction stage (on-site) of 51.687\% [20]. Other research on buildings in Malaysia states that the energy consumed in concreting work in the material production process has a significant greatest amount of energy compared to the construction process. When using the cast-in-place method of material production, the energy consumption is $85.6 \%$, comparedto the construction of $14.4 \%$. While when using the precast method, the energy consumption is $84.1 \%$ in the production process, compared to $15.9 \%$ in the construction process. However, of the two methods, the biggest energy consumed is in the cast-in-placemethod compared to precast (fabrication)method, with a total energy difference of 2-5\% [21].

In efforts to maximize energy efficiency, all construction stakeholders, i.e. the clients, consultants, and contractors must have prime commitment to implement the principles of energy efficiency, low-energy, and net-zero energy building and have a common standard, as this concept is closely related to the use of energy in producing materials and other products at the production stage [22]. Energy efficiency is one of the key components to tackle climate change and to improve the security and availability of energy supplies and resource efficiency [23]. Research on several road constructions in Korea found that precast prestressed concrete girders have the highest levels of emissions consumption especially in material $(131,120 \mathrm{tCO} / \mathrm{km})$, which indicate that steel box girder is considered more environmentally friendly [24].

This research found that the amount of energy produced depends on the location where the main materials and components are produced. When the need for the machinery and materials to produce them is large and varied, so as the energy consumption particularly from fossil fuels. At a certain point, the option for using conventional or precast girders is determinedby the project location. If the project location has a high degree of difficulty, such as having a great distance from concrete manufacturing, or is difficult to reach by transportation to transport the fabricated materials, then conventional girders with the cast-in-place method can the best option. On the other hand, if the access is relatively easy and the distance is not too far between the project location and the concrete manufacturer, the precast girders will be the best option which are moreefficient and low-energy consumption.

\section{Conclusion}

This research quantifies the amount of energy consumption of conventional and precast girders in a case study of the Salatiga-Kartasura Toll Road Package 4.1. This study found that there is a significant difference in the energy consumption of the two. For the conventional girders, the consumption of energy at the raw material transporting stage is $2.857 \mathrm{MJ} / \mathrm{km} . \mathrm{m}^{3}$ $(4.87 \%)$, the production stage is $19.98 \mathrm{MJ} / \mathrm{km} \cdot \mathrm{m}^{3}(34.11 \%)$, at the stage of transporting to the site is $3.56 \mathrm{MJ} / \mathrm{km} \cdot \mathrm{m}^{3}(6.07 \%)$, and at the construction stage is $32.201 \mathrm{MJ} / \mathrm{km} \cdot \mathrm{m}^{3}(54.94 \%)$. While for the precast girders, the consumption of energy at the transporting raw material stage is $2.897 \mathrm{MJ} / \mathrm{km} \cdot \mathrm{m}^{3}(5.27 \%)$, the production stage is $49,627 \mathrm{MJ} / \mathrm{km} \cdot \mathrm{m}^{3}(90.29 \%)$, at the stage of transporting to the site is $0.957 \mathrm{MJ} / \mathrm{km} \cdot \mathrm{m}^{3}(1.74 \%)$, and at the construction stage is $1.485 \mathrm{MJ} / \mathrm{km} \cdot \mathrm{m}^{3}(2.7 \%)$.

This study also found that the total amount of energy consumption of conventional girders is 
$58.606 \mathrm{MJ} / \mathrm{km} \cdot \mathrm{m}^{3}(51.60 \%)$, whereas in precast girder is $54.965 \mathrm{MJ} / \mathrm{km} \cdot \mathrm{m}^{3}(48.40 \%)$. The energy consumption of the conventional girders is greater than the precast girders by $3.641 \mathrm{MJ} / \mathrm{km} . \mathrm{m}^{3}$ $(3.20 \%)$. Thus, in this case, the precast girder can the best option to reduce the energy consumption during toll road construction activities. Furthermore, in the planning of bridge construction projects, it is advisable to pay attention to other factors, such as the condition of the equipment, the distance of mobilization, the skills of the operator, and the volume of materials, to consistently reduce the amount of energy consumption and carbon emissions in each construction activity from the material transporting stage, production, transporting to the site, and construction. By managing these factors systematically and carefully, the environmental damage due to the energy consumption and the greenhouse gases in construction activities can be reduced more optimally. While this research merely focuses on the girders of the bridge, further research may estimate the whole components of the bridge, so that the total energy consumption of a bridge project can be understood more thoroughly.

\section{References}

[1] UNEP, Resources efficiencyin Buildings, (2015)

[2] J. Goggins, Sustainability and Embodied Energy (and Carbon) in Buildings, IBCI Building Control Conference 2012|,28-29 March 2012, Athlone, Ireland(2012)

[3] M. Marzouk, E.M. Abdelkader, M. El-zayat, Aboushady, Sust.9, 843 (2017)

[4] GBCI, Greenship Assessment Tool, Greenship For New Buildings Version 1.2 Summary of Criteria and Benchmarks, Jakarta (2013)

[5] EPA, Progress Report 2010, Air, Climate, Energy, Washington DC, US (2010)

[6] USGBC, Building and Climate Change, US (2015)

[7] J.U.D. Hatmoko, Green Building for Sustainable Development. Proceedings of the National Integrated Technology Seminar in Realising Green Concrete Construction, Civil Engineering Department, Faculty of Engineering, Diponegoro University, November 2010, Semarang, Indonesia (2010)

[8] Greenroad V1.0 Manual, Seattle, US(2010)

[9] E. Greenberg, ITE J.78, 73-84 (2008)

[10] A. Setiawati \& S.C.A. Prasetyo, thesis, Civil Engin. Depart., UNDIP, Indonesia (2014)

[11] V. Penadés-Plà, T. García-Segura, J. V. Martí \& V. Yepes, Sust 10(3), 1-17(2018)

[12] W.F Chen \& L. Duan, Bridge Engineering Handbook, London, UK(2014)

[13] E.G. Nawy, Concrete Construction Engineering Handbook, NW, USA(2008)

[14] Gervásio, Helena, Sim, Luís., Struc. Infra. Engin.4,251-269(2008)

[15] AIA, Guide to Building Life CycleAssessmentin Practice, Washington, USA.(2010)

[16] G. Du, M. Safi, L.Pettersson \& R. Karoumi, I.J.LCA 19(12), 1948-1964(2014)

[17] IPCC, Climate Change 2014, NY,USA.(2014)

[18] M. Espinoza, N. Campos, R. Yang, J.P. Aguiar-Moya, H. Ozer, L. Baldi, L.G. LoríaSalazar and I.L. Al-Qadi, Sust. 11, 2276, (2019)

[19] J. Krantz, J. Larsson, W. Lu and T. Olofsson, J. Build 5, 1156-1170 (2015)

[20] J.U.D. Hatmoko, H. Arif, S. Apsariand C.A.P. Stefanus Measuring Carbon Footprint of Flexible Pavement Construction Project in Indonesia, E3S Web of Conferences 31, 07001 (2018), ICENIS 2017, (2018)

[21] T.J. Wen, H.C. Siong, Z.Z. Noor, Eng\& Build 93, 295 - 302 (2015)

[22] M. Balouktsi\& T.Lützkendorf, Eng.Tech. 4 (1)31-43 (2016)

[23] Euro. Com. DGEnviro, TI 49, 4 (2015)

[24] Y. Seo, and S.M. Kim, Renew. \& Sust. Eng. Rev., 26, 625-631 (2013). 